\title{
An Effective Platform for International Arbitration: Raising the Standards in Speed, Costs and Enforceability
}

\author{
Cavinder Bull*
}

\begin{abstract}
This chapter will discuss how international arbitration institutions have been innovating and improving rapidly in the last few years in order to meet the needs of users. Institutional rules have introduced provisions for emergency arbitrators, expedited proceedings and summary dismissal, just to name a few. Whilst there is still room for improvement, such innovations have helped to keep arbitration relevant and effective. The competition between various arbitral institutions has also contributed positively to spur arbitral institutions to do better. The beneficiaries of this dynamic are the parties that use international arbitration for dispute resolution as well as international trade more generally.
\end{abstract}

\section{Introduction}

Arbitral institutions have experienced a growth spurt in recent years, and are playing a critical role in developing and raising standards in the practice of international commercial arbitration. ${ }^{1}$ The arbitral institutions of today have moved beyond providing administrative and logistical support and have taken a pro-active role in shaping the course of the arbitral process. ${ }^{2}$ More fundamentally, arbitral institutions have demonstrated initiative in adapting to the needs of their users.

* Cavinder Bull, Vice-President of the Court of Arbitration of the Singapore International Arbitration Centre (SIAC), Vice-President of the Asia Pacific Regional Arbitration Group, member of the Governing Board of the International Council for Commercial Arbitration, CEO, Drew \& Napier LLC, Singapore, Cavinder.Bull@drewnapier.com. The author expresses his thanks to Toh Ming Min for her assistance with this chapter.

1 Menon 2018, para 12.

2 Siblesz, 25 April 2013, 1.

(C) ASIAN INFRASTRUCTURE INVESTMENT BANK (AIIB), 2019 | DOI:10.1163/9789004407411_003

This is an open access chapter distributed under the terms of the CC-BY-NC 4.o License. 
Since speed, costs and enforceability are some of the users' primary concerns, arbitral institutions have responded with innovations to improve and develop the system. These include, among others, emergency arbitrator provisions, expedited procedures and early dismissal provisions. The increasing number of applications on the basis of these provisions is evidence of their utility and popularity amongst users.

A positive atmosphere of professional competition between the arbitral institutions has spurred each institution to innovate and improve on the innovations of others. This is geared toward meeting the needs of disputants, thus raising the standards in speed, costs and enforceability. Each innovation that is proven to do its job well establishes itself as an essential part of the system and shifts from innovation to norm as other arbitral institutions adopt and improve upon what was once novel. The ultimate beneficiaries of this dynamic are the parties that use international arbitration for dispute resolution as well as international trade more generally.

Section 2 of this chapter will consider three aspects of arbitration that parties consider important when resolving their disputes using international commercial arbitration-namely, speed, costs and enforceability. Section 2 will also show how arbitral institutions are best placed to effect meaningful changes and improve the quality of arbitration practice. Section 3 examines specific innovations that arbitral institutions have implemented to meet the demands of users by making the arbitration process more expeditious and less costly while ensuring awards of high quality which are enforceable. Section 4 observes how competition between the arbitral institutions has encouraged such innovations and constant advancement, creating a dynamic that yields benefits for users of the system.

\section{Speed, Costs and Enforceability in Arbitration}

Arbitration has risen as the leading forum for the resolution of international commercial disputes. ${ }^{3}$ Indeed, parties choose arbitration as their preferred choice of dispute resolution for good reason. ${ }^{4}$ Foremost amongst those reasons is that of enforceability - perceived as arbitration's most valuable characteristic. ${ }^{5}$ Success in an arbitration would be but a Pyrrhic victory if the award is not enforceable. ${ }^{6}$ Although statistics show that there is a high degree of voluntary

3 Aravena-Jokelainen and Wright 2017, 391.

4 Queen Mary University of London and White \& Case 2018, 2.

5 Ibid; Born, International Commercial Arbitration 2014, 78.

6 Lew, Mistelis and Kröll 2003, para 26-1. 
compliance with arbitration awards, ${ }^{7}$ such voluntary compliance comes about precisely because there is a framework within which awards can be effectively enforced when not complied with. ${ }^{8}$ With the New York Convention, an arbitral award can be brought to 159 jurisdictions, ${ }^{9}$ and enforced in the national courts of those jurisdictions subject to a limited number of exceptions..$^{10}$

That being said, arbitration practice is still growing and there is room for improvement where costs and speed are concerned. One of the orthodox advantages cited in favour of arbitration was that it offered a more cost and time effective means of dispute resolution than national court proceedings since arbitral awards are final and do not involve lengthy appeals. ${ }^{11}$ However, disputants have been raising concerns that 'arbitration proceedings have increasingly been conducted in the manner of litigation', which may erode the costs and speed advantages formerly specific to arbitration. ${ }^{12}$ Cost concerns are tightly intertwined with the speed at which the arbitration progresses since a large part of costs incurred is attributable to the fees and expenses of the parties' legal representatives..$^{13}$ A 2015 study by the International Chamber of Commerce (ICC) Commission on Arbitration and Alternative Dispute Resolution found that arbitrators' fees and expenses accounted for only $15 \%$ of the costs of arbitration; administrative fees made up another $2 \%$; while the remaining $83 \%$ was made up of lawyers' fees and other party costs. ${ }^{14}$ Therefore the most significant way costs can be reduced is by encouraging greater efficiency in the disposal of disputes. ${ }^{15}$

Arbitral institutions are ideally situated to address these issues and enhance the appeal of arbitration practice with changes to their institutional rules. 80\% of respondents to the Queen Mary Survey 2018 consider arbitral institutions 'best placed to influence the future evolution of international arbitration'. ${ }^{16}$ This is unsurprising. Arbitral institutions are natural catchments for the ingathering of a significant number of disputes as an increasing number of arbitration cases are being referred to institutions rather than left to ad hoc arbitration. In Asia, the Singapore International Arbitration Centre (SIAC) handled $45^{2}$ new

7 Queen Mary University of London 2008, 8 and 10.

8 Lew, Mistelis and Kröll 2003, para 26-1.

9 See the list of contracting states on the New York Arbitration Convention website available online at: <http://www.newyorkconvention.org/countries > accessed 28 June 2018.

10 The New York Convention, arts II I-V; Born, International Commercial Arbitration 2014, 78.

11 Born, International Commercial Arbitration 2014, 86; Aravena-Jokelainen and Wright 2017, 393 .

12 Aravena-Jokelainen and Wright 2017, 395.

13 Blackaby and others 2015, para 1.124.

14 ICC, 'ICC Commissions Report' 2015, 3.

15 Menon 17 May 2018, para 21.

16 Queen Mary University of London and White \& Case 2018, 3. 
cases in 2017, and $93 \%$ or 421 of those new cases were SIAC-administered. ${ }^{17}$ The Hong Kong International Arbitration Centre (HKIAC) handled 297 new arbitration cases in 2017, and 156 of these new cases were administered by HKIAC - a 66\% growth from 2016.18 A 2015 International Arbitration Survey showed that $79 \%$ of the arbitrations that the respondents had taken part in over the preceding five years were institutional rather than ad hoc. ${ }^{19}$ It is evident that any change in an arbitral institution's rules would have the potential to affect hundreds of cases that are conducted in accordance with those rules.

Arbitral institutions have the opportunity now to apply their influence toward elevating the practice of international arbitration - passively allowing this opportunity to pass without active participation would be tantamount to abdicating responsibility. Singapore's Chief Justice Sundaresh Menon stated at the SIAC Congress 2018 Keynote Address that whereas 'as recently as two decades ago, few would have said that arbitral institutions had any role in shaping the future of international arbitration', today the modern arbitral institution is more than just an administrative body - today it plays a 'vital role at every stage in the life cycle of an arbitration' and a 'prominent role in thought leadership'. ${ }^{20}$ How have arbitral institutions been employing such potential to influence? They have become 'engines of procedural change' through the implementation of innovative provisions in their institutional rules. ${ }^{21}$ As will be seen below, the increasing demand for the use of the innovations already implemented attests to their effectiveness in meeting the needs of users. Once novel procedures are test-driven and proven to serve their purposes, other institutions are swift to adapt and implement the same. These innovative institutional rules then gradually become the norm and establish themselves as part of the stable landscape of international arbitration.

In this part, we will examine examples of innovations that arbitral institutions have used to raise standards in speed, cost-effectiveness and enforceability: the emergency arbitrator provision, the expedited procedure, early dismissal of claims and defences, institutional investment arbitration rules and the Arb-Med-Arb Protocol (AmA Protocol).

\footnotetext{
17 SIAC, 'Annual Report' 2017, 11.

18 HKIAC, '2017 Statistics'.

19 Queen Mary University of London and White \& Case 2015, 17.

$20 \quad$ Menon, 17 May 2018, paras 1-2.

21 Rau and Sherman 1995, 94.
} 


\subsection{Emergency Arbitrator}

In 2010 the SIAC was the first Asian institution to introduce an innovation which allowed a party to seek interim relief from an emergency arbitrator prior to the constitution of the tribunal (Rule 30.2 of the 2010 Arbitration Rules of the SIAC (2010 SIAC Rules)), and continued into the current 2016 Arbitration Rules of the SIAC (2016 SIAC Rules)..$^{22}$ Before the introduction of this innovation, parties in need of urgent interim relief prior to the constitution of the tribunal had to seek relief from a national court. This process was not only potentially costly and dilatory; parties also had concerns about the neutrality of the court and about the confidentiality of proceedings. ${ }^{23}$ Having to turn to a national court for interim relief 'undermin[ed] the very reason why parties chose arbitration' in the first place. ${ }^{24}$

The emergency arbitrator provision allowed a party to seek interim relief expeditiously. Upon the application for emergency interim relief, the SIAC President shall, if he determines that the siAC should accept the application, seek to appoint an emergency arbitrator within one day of receipt of such application. ${ }^{25}$ This is an improvement from the 2013 Arbitration Rules of the SIAC (2013 SIAC Rules) which mandated that the sIAC President should appoint the emergency arbitrator within one business day. ${ }^{26}$ The emergency arbitrator must then, within two days of his appointment, establish a schedule for consideration of the application for emergency interim relief. A hearing in person may be dispensed with in favour of proceedings by telephone or video conference or on written submissions. ${ }^{27}$ The order or award of interim relief must be issued within a maximum of 14 days from the appointment of an emergency arbitrator. ${ }^{28}$ This also is an improvement from the 2013 SIAC Rules which did not contain any time limit for the emergency arbitrator to issue his order or award. ${ }^{29}$

The popularity of the emergency arbitrator provision is a testimony to its effectiveness. ${ }^{30}$ There have been 72 applications for emergency interim relief in the SIAC since July 2010, and all were accepted. ${ }^{31}$ When the provision first appeared in 2010, SIAC only received 2 applications under the emergency

\footnotetext{
22 SIAC, 'CEO's Annual Report' 2011, 3.

23 Choong, Mangan and Lingard 2018, para 13.17.

24 Ibid

25 See SIAC, Arbitration Rules 2016, sch 1, para 3.

26 See SIAC, Arbitration Rules 2013, sch 1, para 3.

27 See SIAC, Arbitration Rules 2016, sch 1, para 7.

28 See ibid, para 9.

29 Dulac and Lo 2016, 148.

30 Choong, Mangan and Lingard 2018, para 13.19.

31 SIAC, 'Annual Report' 2017, 11.
} 
arbitrator provision..$^{32}$ In 2017 there were 19 applications for emergency interim relief and all were accepted. ${ }^{33}$

As one of the pioneers of emergency arbitration, the success of sIAC's emergency arbitrator procedure can be attributed to the efficient manner in which cases have been processed. SIAC emergency arbitrators needed on average 2.5 days to issue the first interim order after the request for emergency relief and only an average of eight and a half days to render an award on interim relief after the first interim order. ${ }^{34}$ The express duties emergency arbitrators owe pursuant to Schedule 1 of the 2016 SIAC Rules are supplemented by further express duties set out in the SIAC Code of Ethics for an Arbitrator (Code of Ethics). ${ }^{35}$ The Code of Ethics requires that a prospective arbitrator accept such an appointment only if inter alia he has an adequate knowledge of the language of the arbitration, and he is able to give to the arbitration the time and attention which the parties are reasonably entitled to expect: ${ }^{36}$ Having an adequate knowledge of the language of the arbitration ensures that proceedings run smoothly as the arbitrator can quickly grasp the facts and arguments presented and properly understand the dispute in a familiar language.

Since one reason for inefficiency in arbitration proceedings is that of arbitrator unavailability, the sIAC has made efforts to ensure that the emergency arbitrators appointed are committed to an expeditious arbitration. ${ }^{37}$ sIAC's list of potential emergency arbitrators is limited to those who in their application form for admission to the SIAC Panel of Arbitrators, state that they are willing to act as an emergency arbitrator. ${ }^{38}$ Having to make an affirmative indication of willingness to act on short notice on an expedited timeframe encourages commitment from arbitrators who do indicate such willingness. The Code of Ethics also mandates that should the prospective arbitrator be aware of any potential time constraints in their ability to discharge their duties if they are appointed as an arbitrator, they are required to disclose details of such time constraints to the Registrar of the SIAC. ${ }^{39}$ The SIAC in turn reserves the right to refuse to appoint the prospective arbitrator should it take the view that the prospective arbitrator will not be able to discharge his duties due to such

\footnotetext{
32 SIAC, 'CEO's Annual Report' 2010, 3.

33 SIAC, 'Annual Report' 2017, 11.

34 Kim 2014, 20.

35 Giaretta 2012, 215.

$36 \quad$ SIAC, Code of Ethics 2015, para 1.1.

37 Da Silva 2017, 27.

38 See siAc, 'Application Form for Admission to Panels'.

39 SIAC, Code of Ethics 2015, para 1.2.
} 
potential time constraints. ${ }^{40}$ This minimizes the potential of arbitrators overscheduling themselves and then finding it difficult to fully commit or give the SIAC arbitration the due time and attention it deserves. The Code of Ethics establishes that any failure by the prospective arbitrator to discharge their duties to ensure the fair, expeditious, economical and final determination of the dispute may be taken into account by the Registrar of the SIAC when fixing the quantum of fees payable to the arbitrator. ${ }^{41}$ The potential of a sanction on the arbitrator's fees for a less-than-expeditious arbitration incentivizes the arbitrator to speed up the process; and if an arbitrator bears this potential sanction in mind when offered with an appointment as arbitrator, they are more likely to accept the appointment only when they are sure they can be fully committed to an expeditious arbitration.

While some express concerns that the benefits of emergency arbitration may be undermined by uncertainty over the enforceability of interim measures issued by arbitrators, ${ }^{42}$ institutional solutions have the ability to ensure the enforceability of emergency arbitrator awards. Singapore has amended arbitration laws to allow for enforcement of emergency arbitration awards, which ensures that decisions of emergency arbitrators are enforceable, regardless of what the nature of an emergency arbitrator is and what the decision is called. ${ }^{43}$ SIAC reported that the parties in the first 21 completed cases in which an emergency arbitrator was appointed either complied with the emergency arbitrator's award voluntarily or settled the dispute soon thereafter. ${ }^{44}$

The use of the emergency arbitrator mechanism is also found in other arbitral institutions. The emergency arbitrator provision has been part of the Arbitration Rules of the Arbitration Institute of the Stockholm Chamber of Commerce (SCC) since 1 January 2010.45 As of June 2017, the sCC has seen a total of 27 applications for the appointment of an emergency arbitrator, with 13 of those received in 2016 alone. ${ }^{46}$ In 2012, the ICC Arbitration Rules similarly introduced the role of the emergency arbitrator, ${ }^{47}$ and in 2017, 21 emergency arbitrator applications were filed with the ICc. ${ }^{48}$

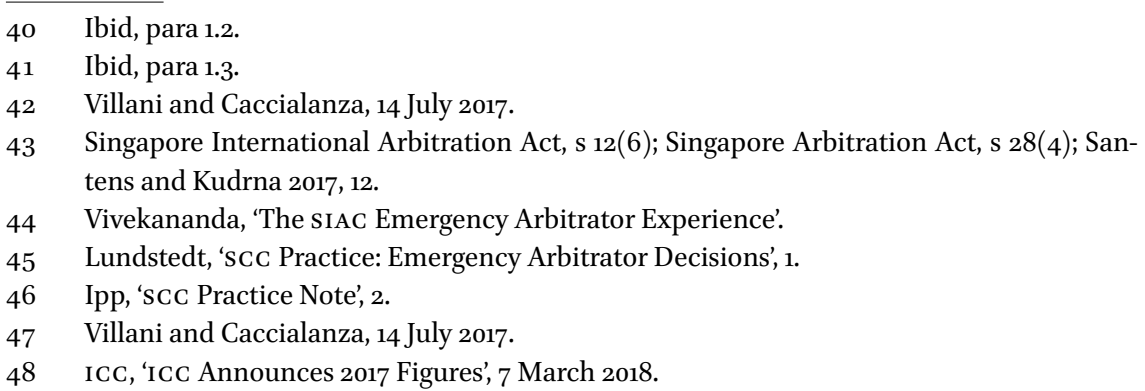




\subsection{Expedited Procedure}

Another innovation which has improved arbitral offerings is the expedited procedure. For example, Rule 5 of the 2016 SIAC Rules provides for expedited procedures. This innovation was introduced in 2010 and allows a party to apply for an arbitration to be conducted on an expedited basis and to be completed within six months from the date the tribunal is constituted if the aggregate sum in dispute does not exceed $\$ \$ 6$ million, all parties agree, or in cases of exceptional urgency. The expedited procedure allows the tribunal to state its reasons for deciding in summary form. ${ }^{49}$

The expedited procedure, as its name suggests, improves the speed at which disputants can resolve their disputes, especially the smaller or less complex cases. The tribunal may conduct any hearing via video conference, telephone, or similar means of communication. ${ }^{50}$ Rule 5.2 (c) of the 2016 SIAC Rules gives the tribunal the discretion to decide, upon consultation with the parties, whether the dispute is to be decided on the basis of documentary evidence only or if a hearing is required. The tribunal may thus choose to conduct the arbitration on the basis of documentary evidence alone if it considers that to be appropriate.

This is an improvement from the 2013 SIAC Rules, where the tribunal was required to hold a hearing unless the parties agree otherwise. ${ }^{51}$ It has been said that where the sum at stake is relatively small, there is a higher chance of the respondent not participating in the arbitration. ${ }^{52}$ When this happens, under the former 2013 SIAC Rules, the tribunal would still have had to hold a hearing since the respondent in default would not have agreed to dispense with the hearing and proceed only on the documentary evidence; whereas under the 2016 SIAC Rules, a hearing could be dispensed with.

In practice, the quality of awards has not been compromised despite the fact that brevity is acceptable in expedited cases given the emphasis on efficiency. The SIAC Secretariat has reported that tribunals in expedited cases 'often do not appear to take advantage of the opportunity to submit an award with summary reasons. ${ }^{53}$ Where the parties agree that the tribunal need not issue reasons in support of its decision, the enforceability of the award is not eroded since it would be very difficult for either party to challenge the resulting

\footnotetext{
49 See siAC, Arbitration Rules 2016, r 5.2.

$5^{\circ} \quad$ Choong, Mangan and Lingard 2018, para 6.29.

51 See SIAC, Arbitration Rules 2013, r 5.2(c).

52 Dulac and Lo 2016, 148.

53 Choong, Mangan and Lingard 2018, para 6.34.
} 
award on the grounds that no reasons were stated. In fact, such an agreement to dispense with a reasoned decision, as Rules 32.4 and 5.2(e) of the 2016 SIAC Rules allow, is treated as an 'exclusion of the parties' right to appeal questions of law to the Singapore High Court.'54

The expedited procedure has proven to be popular in the SIAC. In 2017 alone, there were 107 applications for Expedited Procedure, of which 55 applications were accepted. As of ${ }_{31}$ December 2017, since the procedure was introduced in 2010, there have been 414 applications for Expedited Procedure, with 236 having been accepted..$^{55}$

In March 2017, the ICC introduced its expedited procedures through a new Article 30 and a new Appendix VI to the ICC Arbitration Rules (ICC Rules). ${ }^{56}$ The ICc has adapted the expedited procedure into an 'opt out' procedure, unlike the SIAC's 'opt in' provision, such that it will apply automatically if the amount in dispute does not exceed US $\$ 2$ million. ${ }^{57}$ Formerly, the ICC's stance was that it would recognise the parties' right to agree to shorten the various time limits set out in the ICC Rules and encourage parties to use case management techniques. However, in practice, the strong emphasis on case management techniques in the 2012 ICC Rules did not fully accomplish the desired results in practice..$^{58}$ Therefore the ICc decided to impose the expedited procedure for small claims with the possibility of opting out. ${ }^{59}$ The H KIAC has also substantially increased the threshold for expedited procedures to $\mathrm{HK} \$ 25$ million as of November 2013. ${ }^{60}$ This represents a nearly 13-fold rise from the previous threshold from 2010 and this new threshold is much closer to sIAC's S\$6 million threshold. ${ }^{61}$ The higher threshold allows the H KIAC to offer a larger pool of disputants the option of an expedited procedure.

\subsection{Early Dismissal of Claims and Defences}

SIAC is the first international commercial arbitral institution to introduce a procedure for the early dismissal of claims and defences. Under Rule 29 of the 2016 sIAC Rules, a party may, at any time after the constitution of the tribunal, file an application to the tribunal for the early dismissal of a claim on the

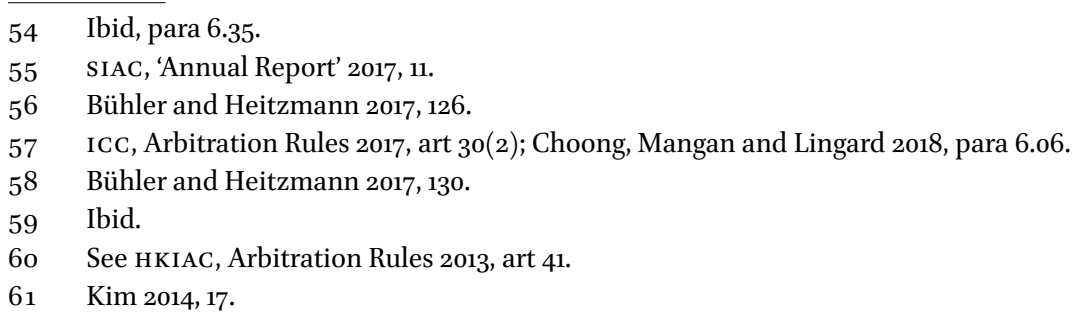


ground that (i) the claim is manifestly without legal merit; or (ii) the claim is manifestly outside the jurisdiction of the tribunal. The application must state 'in detail the facts and legal basis supporting the application', and the tribunal may, in its discretion, allow the application to proceed. ${ }^{62}$ The tribunal must decide any such application for early dismissal within 6o days of the filing of the application. ${ }^{63}$ Rule 29 is meant to allow a tribunal to dismiss unmeritorious claims without labouring through lengthy proceedings, and as such save time and costs by bringing proceedings that have an obvious outcome to an end as early as possible. ${ }^{64}$

Although still in its nascent stages, there have already been five early dismissal applications in the SIAC in 2017. Of the five applications received, four were allowed to proceed under Rule 29.3 of 2016 siAC Rules, and one was pending as of 31 December 2017. ${ }^{65}$

The early dismissal provision has been described as cutting-edge innovation that differentiates SIAC from other institutions; however, it was also noted that if the procedure works well, other major arbitral institutions are likely to adopt it. ${ }^{66}$ In fact the SIAC's Rule 29 itself drew its inspiration from Rule 41(5) and 41(6) of the ICSID Rules of Procedure for Arbitration Proceedings 2006 (ICSID Rules). ${ }^{67}$ ICSID was the first major international arbitral institution to introduce a provision on early dismissal (Rule 41(5) of the ICSID Rules). After the SIAC introduced summary disposal procedures to the commercial arbitral institution in 2016, the SCC introduced a similar procedure in 2017. ${ }^{68}$ Article 40 of the Arbitration Rules of the Arbitration Institute of the Stockholm Chamber of Commerce in force as of 1 January 2017 provides that a party may request that the Arbitrator decide one or more issues of fact or law by way of summary procedure, without necessarily undertaking every procedural step that might otherwise be adopted in the arbitration. ${ }^{69}$ Similarly the ICC has very recently recognized the tribunal's power for summary determination. Although not provided expressly in its arbitration rules, the power of summary

\footnotetext{
62 Dulac and Lo 2016, 145 .

63 Choong, Mangan and Lingard 2018, para 3.26.

64 Dulac and Lo 2016, 145; SIAC, 'Highlights of the SIAC Rules 2016', 30 June 2016, 1.

65 SIAC, 'Annual Report' 2017, 11.

66 Secomb and Tahsin, 'sIAC Unveils New, Innovative Rules', 11 July 2016.

67 Dulac and Lo 2016, 143.

68 The Arbitration Institute of the Stockholm Chamber of Commerce, Arbitration Rules 2017, art 39; the Arbitration Institute of the Stockholm Chamber of Commerce, Rules for Expedited Arbitrations 2017, ar 40.

69 Banifatemi 2017, 16 .
} 
determination is recognized in the ICC's Practice Note to Parties and Arbitral Tribunal on the Conduct of Arbitration. ${ }^{70}$

\subsection{SIAC Investment Arbitration Rules}

Another exciting innovation is that of the Investment Arbitration Rules of the SIAC (1st Edition, 1 January 2017) (sIAC IA Rules), which came into force on 1 January 2017 and are the first full set of rules customized for international investment arbitration to be released by a commercial arbitration centre. ${ }^{71}$ The SIAC IA Rules contain a number of provisions that have no corresponding provisions in the SIAC Rules. ${ }^{72}$ For instance Rule 29.2 of the sIAC IA Rules provides that potential amici curiae may 'apply to the tribunal for the right to submit a brief' as a non-disputing party. ${ }^{73}$ The sIAC IA Rules also provide the tribunal with the power to order parties to disclose third party funding arrangements, the identity of the funder, and any other details which the tribunal deems necessary. The tribunal may also take into account any third party funding arrangements when determining the allocation of costs. ${ }^{74}$

The SIAC IA Rules indicate that SIAC aims to maintain and further improve efficiency in the investment arbitrations to be administered under its rules. For instance, Rule 16.5 of SIAC IA Rules provides that the presiding arbitrator may make procedural rulings alone. It has been said that such broad procedural powers in the absence of parties' agreement to that effect potentially reduces the kind of 'procedural deadlocks' that may occur in investor-state disputes. ${ }^{75}$ The sIAC IA Rules also contain strict time limits to avoid undue delay-with time limits that are shorter than those found in the ICsID Rules. ${ }^{76}$ For instance, the SIAC IA Rules provide that, if within 42 days after the date of commencement of the arbitration, the parties have not reached an agreement on the nomination of a sole arbitrator, the SIAC Court shall appoint the sole arbitrator; and if a party fails to nominate its arbitrator within 35 days after receipt of the other party's nomination of its arbitrator, the SIAC Court may proceed to appoint the arbitrator on its behalf (Rules 9.1 and 7.2 of the SIAC IA Rules). On the other hand, in an ICSID arbitration, where parties do not agree on the method of constitution of the tribunal, either party after go days may make a

\footnotetext{
$70 \quad$ ICC, 'Note on the Conduct of the Arbitration' 2017, 11.

71 SIAC, Investment Arbitration Rules 2017; Choong, Mangan and Lingard 2018, para 3.27.

72 Choong, Mangan and Lingard 2018, para 19.10.

73 Lamb, Harrison and Hew 2016, 78.

74 SIAC, Investment Arbitration Rules 2017, $\mathrm{rr} 24$ and 31.

75 Boog and Wimalasena 2017, 79.

76 ICSID, Rules of Procedure for Arbitration 2006; Choong, Mangan and Lingard 2018, para 19.11.
} 
request that ICSID appoint the arbitrators (Rule 4(1) of the ICSID Rules). The time limit for the submission of the award is also regulated by both the SIAC and the ICSID Rules. Rule 30 of the SIAC IA Rules provides that an award shall be submitted to the Registrar of SIAC not later than 90 days from the date on which the tribunal declares the proceedings closed. The time limit may be extended pursuant to Rules 30.3 and 2.6 of the siaC IA Rules. In contrast, Rule 46 of the ICSID Rules states that the award shall be rendered within 120 days from the closure of the proceedings, and that the tribunal itself may extend this period by a further 60 days if it would otherwise be unable to draw up the award.

Furthermore, the jurisdictional threshold under the sIAC IA Rules only requires that the parties have agreed to arbitrate under these rules. The introduction to the SIAC IA Rules states expressly that the SIAC IA Rules may be agreed and applied in any type of arbitration, 'the application of which shall not be subject to objective criteria, such as the existence of a qualifying "investor" or "investment" or the presence of a State, State-controlled entity or intergovernmental organisation, without prejudice to any requirements set out in the underlying contract, treaty statute or other instruments. ${ }^{77}$ The parties' agreement may be in writing, but may also result from implied consent-Rule 1.2 provides that a party is deemed to have consented to the application of the SIAC IA Rules if, following an offer in writing from the other party, it initiates arbitration proceedings. In contrast, under Article 25(1) of the ICSID Convention, ${ }^{78}$ in order to establish jurisdiction over a dispute that has been submitted to ICSID, an ICSID tribunal must satisfy itself that inter alia the dispute arises directly out of an 'investment'. This has given rise to debates over the meaning of the term 'investment' under the ICsID Convention and has been a 'major procedural obstacle' for parties claiming under a bilateral investment treaty which provides for ICSID arbitration. ${ }^{79}$ It is said that more than a quarter of all awards currently rendered by ICSID tribunals are awards rejecting jurisdiction primarily due to findings that there was no 'investment' pursuant to Article 25(1) of the ICSID Convention. ${ }^{80}$

SIAC's approach which does not depend on issues of 'investment' is likely to expedite the arbitration significantly by avoiding lengthy preliminary disputes on jurisdiction. There may still be jurisdictional arguments as to whether the dispute falls under the relevant contract, BIт or other instrument; however, the

77 Choong, Mangan and Lingard 2018, para 19.13.

78 Convention on the Settlement of Investment Disputes between States and Nationals of Other States, art 25.

79 Boog and Wimalasena 2017, 75 .

8 Ibid. 
SIAC IA Rules does away with time-consuming arguments as to the applicability of the SIAC IA Rules where terms such as 'investor' are concerned.

The administration costs and tribunal fees for an arbitration under the sIAC IA Rules will generally be lower than the equivalent costs and fees of an arbitration under the ICSID Rules. ${ }^{81}$ This is because the Schedule of Fees under the SIAC IA Rules is the same as the Schedule of Fees in the SIAC Rules for standard SIAC arbitrations. ${ }^{82}$ For instance sIAC charges a fixed filing fee of $\mathrm{S} \$ 2,000$ as compared to a filing fee of US $\$ 25,000$ under the ICSID Rules. Further, the administration fee for an arbitration under the SIAC IA Rules ranges from $S \$ 3,800$ to $S \$ 95,000$ depending on the amount in dispute, whereas ICSID charges a fixed administration fee of US $\$ 42,000$ for each year of the arbitration. Under the SIAC IA Rules, the arbitrator's total fees are calculated on the basis of the amount in dispute, with the minimum fee set at $\$ \$ 6,250$ up to a maximum of $\$ \$ 2,000,000$. Parties may also agree to an alternative method of determining the arbitrators' fees pursuant to Rule 32.1. In comparison, arbitrators in ICSID proceedings are entitled to receive a fee of US $\$ 3,000$ per day of meetings or other work performed in connection with the proceedings. Since under the SIAC IA Rules, the arbitrator fees are not dependent on how much time is spent on the dispute and instead are fixed according to the sum in dispute, there will be no incentive for any arbitrator to delay proceedings. From the above, it is evident that arbitrations will generally be more affordable under the SIAC IA Rules unless the amount at stake is relatively high, in which case a party might prefer ICSID's fixed rates instead. ${ }^{83}$ For claimants based in Asia, the benefits of being able to conduct investment arbitrations in Singapore may also be significant. ${ }^{84}$

\subsection{Arb-Med-Arb Protocol}

The AMA Protocol allows a party to initiate SIAC arbitration, then stay the arbitration and submit the case to mediation at the Singapore International Mediation Centre (SIMC). If the mediation is not successful, the matter is referred back to arbitration and concludes with the issuance of an enforceable award. ${ }^{85}$ Parties to the AMA Protocol will have their mediations and arbitrations administered by and under the respective rules of SIMC and SIAC. The arbitrators and mediators will be separately and independently appointed by

81 Khouri, Gayner and Landis, 29 June 2017; Choong, Mangan and Lingard 2018, para 3.30.

82 See SIAC, Arbitration Rules 2016, 41; SIAC, Investment Arbitration Rules 2017, 25.

83 Choong, Mangan and Lingard 2018, paras 3.31-3.32.

84 Khouri, Gayner and Landis, 29 June 2017.

85 Boog 2015, 94 . 
the SIAC and SIMC, respectively - which leads to 'increased confidence in the process insofar as parties can be assured that their respective cases in the arbitration will not be affected by the outcome of the mediation. ${ }^{\prime 6}$ In the event of a settlement of the dispute by mediation, the parties may request the tribunal to record their settlement in the form of a consent award on the terms agreed to by the parties (paragraph nine of the AMA Protocol). A consent award is generally accepted as an arbitral award and therefore is enforceable in New York Convention member states. ${ }^{87}$

Although mediation was traditionally intended to achieve settlement through a less formal process at an early stage and thus save parties the time and cost of formal arbitration or litigation, in practice this has not been the case. ${ }^{88}$ One pitfall parties face is where the mediation clause was not carefully drafted and parties later end up stuck in the initial stages of the dispute resolution process, prolonging instead of rendering the process more efficient. ${ }^{89}$ There is also the potential that the mediation may end up being conducted like a mini-arbitration, rendering it almost as time and cost-consuming as a fully-fledged arbitration. Furthermore, even if mediation is successful, the parties only end up with a mediated settlement agreement which is not easily enforceable. ${ }^{90}$

The Ama Protocol combines the efficiency of mediation and the certainty and enforceability of an arbitral award. ${ }^{91}$ The AM A Protocol is also cost-efficient. The sIMc's administrative fees are available on their website. The selection of appointment of a mediator costs $S \$ 1,000$ per mediator, the booking and setup of venue and refreshments costs another $S \$ 1,000$; the pre-mediation case management costs $S \$ 3,000$ and the actual mediation day case administration costs $S \$ 1,000$ per day. If the dispute is resolved at the mediation stage, evidently the cost savings will be impressive. The AMA Protocol provides rules that co-ordinate filing fees and advances on costs for the arbitration and the mediation stages of the AMA Protocol. For instance, it has been pointed out that parties will have to file only one case filing fee to sIAC for all cases under the AMA Protocol. The 'seamless transition' as parties move across the arbitration and mediation phases is likely to encourage cost-efficiency. ${ }^{92}$

\footnotetext{
86 Chua, 29 December 2014.

87 Ibid.

88 Boog 2015, 92.

89 Ibid.

9o Ibid

91 Schellenberg Wittmer Ltd, 8 January 2015.

92 Boog 2015, 95-96.
} 


\section{Competition between Arbitral Institutions Encourages Innovation and Development}

Competition and innovation constitute the core of modern capitalism, where providers of goods and services vie to take the initiative to improve standards and expand their market share. Even when a product or service reaches a high level of refinement, producers will find ways to improve where costs, speed and quality are concerned. ${ }^{93}$ The evolutionary nature of free markets is such that established ways of doing things will inevitably be replaced by new ones. ${ }^{94}$ Therefore service providers, including arbitral institutions, need to advance with the times and constantly innovate to keep abreast of and be a participant in developments. ${ }^{95}$ Some innovations become so embedded and essential to the system that they have progressed from innovation to norm. ${ }^{96}$ For instance the emergency arbitrator provisions discussed above have become the norm, with virtually all leading arbitral institutions offering emergency arbitration. ${ }^{97}$

As early as 1985, international arbitration was already described as a field of intense competition including competition between arbitral institutions. ${ }^{98}$ In our day, new arbitral institutions, mostly regional, have appeared and started to compete with the old establishment. ${ }^{99}$ It has been observed that new arbitral institutions are constantly growing in stature, caseload and influence that often exceeds their geographical boundaries. Before 1940, only $10 \%$ of the current institutions existed. $70 \%$ of the institutions have been created in the last thirty years only; with $50 \%$ in the last twenty years and $20 \%$ in the last ten. ${ }^{100}$ Each institution is dependent on the funds derived from a strong market position to fulfill their mandates, hence the competition for market share. ${ }^{101}$

Such increased competition is healthy for the arbitration industry as it enables the arbitration industry to perform better and more efficiently. ${ }^{102}$ Arbitral institutions have a collective interest in continually improving themselves so

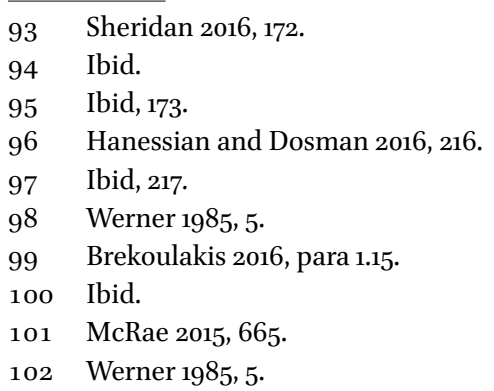


that they remain an 'efficient and cost-effective alternative to litigation in domestic fora.' ${ }^{103}$

Indeed, as seen from the above, the SIAC has been constantly updating its rules, well aware that no arbitral institution today can take its success for granted. ${ }^{104}$ The arbitral institutions of today welcome competition for better solutions and are not reluctant to borrow test-driven foreign solutions. ${ }^{105}$ Just as Singapore and Hong Kong learnt from each other's arbitration legislation in the 199os and progressed to becoming international arbitration powerhouses, ${ }^{106}$ today the SIAC and the HKIAC, along with other international arbitration institutes, learn from one another's innovations and solutions toward improving international commercial arbitration. The bold revisions have reaped rewards - following the introduction of the innovations discussed earlier, a new benchmark was set by SIAC in 2017 with 421 new SIAC-administered case filings. ${ }^{107}$ This represents a $37 \%$ increase from the 307 SIAC-administered cases filed in 2016, and a $73 \%$ increase from the 244 SIAC-administered cases filed in $2015 \cdot{ }^{108}$

That being said, the group that reaps the most benefits from the competitive dynamic that results in arbitral institutions' innovations are the users of the said institutions and their innovations. Disputants seeking more expedient, cost-efficient and yet enforceable awards can bring their claims to the institutions that are innovating and seeking to improve.

As seen from the foregoing, innovations are crucial to arbitral institutions maintaining their key role as effective platforms for international arbitration. The competition between arbitral institutions to garner and protect their market share incentivizes them to find creative solutions to the concerns of disputants. These innovative solutions go toward expediting the arbitral process, reducing costs and ensuring that the arbitral award that results is of high quality and enforceable: all this for the benefit of the users of international arbitration.

\footnotetext{
103 McRae 2015, 665.

104 Born, International Arbitration and Forum Selection Agreements 2016, para 24.

105 Schaefer 1999, 90.

106 Ibid, 89.

107 SIAC, 'Annual Report' 2017, 11.

108 Ibid, 13 .
} 


\section{Reference List}

Aravena-Jokelainen A and Wright S, 'Chapter 16: Balancing the Triangle: How Arbitration Institutions Meet the Psychological Needs and Preferences of Users' in Cole T (ed), The Roles of Psychology in International Arbitration (International Arbitration Law Library Series Volume 40, Kluwer Law International 2017).

Arbitration Act (Cap 10, Rev Ed 2002) section 28(4) (SG).

Arbitration Institute of the Stockholm Chamber of Commerce, Arbitration Rules of the Arbitration Institute of the Stockholm Chamber of Commerce (1 January 2017).

Banifatemi Y, 'Chapter 1: Expedited Proceedings in International Arbitration' in Lévy L and Polkinghorne M (eds), Expedited Procedures in International Arbitration (International Chamber of Commerce 2017).

Blackaby $\mathrm{N}$ and others, Redfern and Hunter on International Arbitration (6th edn, OUP 2015).

Boog C and Wimalasena P, 'The SIAC IA Rules: A New Player in the Investment Arbitration Market' (2017) 6 Indian Journal of Arbitration Law 73.

Boog C, 'The New SIAC/SIMC AMA Protocol: A Seamless Multi-Tiered Dispute Resolution Process Tailored to the User's Needs' (2015) 2 Asian Dispute Review 91.

Born G, International Commercial Arbitration (2nd edn, Kluwer Law International 2014).

Born G, International Arbitration and Forum Selection Agreements: Drafting and Enforcing (5th edn, Kluwer Law International 2016).

Brekoulakis S, 'Introduction: The Evolution and Future of International Arbitration' in Brekoulakis S, Lew J and others (eds), The Evolution and Future of International Arbitration (International Arbitration Law Library Volume 37, Kluwer Law International 2016).

Bühler M and Heitzmann P, 'The 2017 ICC Expedited Rules: From Softball to Hardball?’ (2017) 34 Journal of International Arbitration 121.

Choong J, Mangan M and Lingard N, A Guide to the SIAC Arbitration Rules (2nd edn, OUP 2018).

Chua E, 'A New Dawn for Mediation? The Launch of the Singapore International Mediation Centre (SIMC) and Introduction of the SIAC-SIMC Arb-Med-Arb Protocol' (Kluwer Arbitration Blog 29 December 2014) < http://arbitrationblog. kluwerarbitration.com/2014/12/29/a-new-dawn-for-mediation-the-launch-of-the -singapore-international-mediation-centre-simc-and-introduction-of-the-siac -simc-arb-med-arb-protocol/> accessed 19 July 2018.

Convention on the Settlement of Investment Disputes between States and Nationals of Other States (opened for signature 18 March 1965, entered into force 14 October 1966) 575 UNTS 159 . 
Da Silva JMRM, 'An answer to criticisms against the lack of efficiency in arbitration: measures to reduce time and costs' (2017) 14 Revista Brasileira de Arbitragem 23.

Dulac E and Lo A, 'The SIAC Rules 2016: New Features' (2016) 5 Indian Journal of Arbitration Law 129.

Giaretta B, 'Duties of Arbitrators and Emergency Arbitrators under the SIAC Rules' (2012) 8 Asian International Arbitration Journal 196.

Hanessian G and Dosman EA, 'Songs of Innocence and Experience: Ten Years of Emergency Arbitration' (2016) 27 American Review of International Arbitration 215.

HKIAC, 2013 HKIAC Administered Arbitration Rules (2013) <www.hkiac.org/arbitra tion/rules-practice-notes/hkiac-administered-2013> accessed 22 February 2019.

HKIAC, '2017 Statistics' (Hong Kong International Arbitration Centre) <www.hkiac .org/about-us/statistics> accessed 28 December 2018.

ICC, 'ICC Commissions Report: Decisions on Costs in International Arbitration' [2015] 2 ICC Dispute Resolution Bulletin $1<$ www.iccwbo.be/wp-content/ uploads/2012/03/20151201-Decisions-on-Costs-in-International-Arbitration.pdf> accessed 11 May 2018.

ICC, Rules of Arbitration of the ICC (1 March 2017).

ICC, 'ICC Announces 2017 Figures Confirming Global Reach and Leading Position for Complex, High-value Disputes' (International Chamber of Commerce, 7 March 2018) < https://iccwbo.org/media-wall/news-speeches/icc-announces-2017-figuresconfirming-global-reach-leading-position-complex-high-value-disputes/>accessed 10 July 2018.

ICSID, ICSID Rules of Procedure for Arbitration Proceedings (10 April 2006).

International Arbitration Act (Cap 143A, Rev Ed 2002) section 12(6) (SG).

Ipp A H, 'SCC Practice Note: Emergency Arbitrator Decisions Rendered 2015-2016' (Arbitration Institute of the Stockholm Chamber of Commerce 2017) <www .sccinstitute.com/media/ 194250/ea-practice-note-emergency-arbitrator-decisions -rendered-2015-2016.pdf> accessed 10 July 2018.

Kim J, 'International Arbitration in East Asia: From Emulation to Innovation' (2014) 4 The Arbitration Brief 1.

Lamb S, Harrison D and Hew J, 'Recent Developments in the Law and Practice of Amicus Briefs in Investor-State Arbitration' (2016) 5 Indian Journal of Arbitration Law 72.

Landis N and others, 'SIAC's new Investment Arbitration Rules - another step forward for funding in Asia' (IMF Bentham, 29 June 2017) < www.imf.sg/blog/blog-full-post /imf-bentham-asia-blog/2017/o6/29/siac-s-new-investment-arbitration-rules -another-step-forward-for-funding-in-asia> accessed 10 July 2018.

Lew J D M, Mistelis L A and Kroll S M, Comparative International Commercial Arbitration (Kluwer Law International 2003). 
Lundstedt J, 'SCC Practice: Emergency Arbitrator Decisions: 1 January $2010-31$ December 2013' (Arbitration Institute of the Stockholm Chamber of Commerce) $<$ www.sccinstitute.com/media/29995/scc-practice-2010-2013-emergency-arbitrator _final .pdf $>$ accessed 10 July 2018.

McRae B, 'Introduction to the Session Arbitral Institutions Can Do More to Foster Legitimacy. True or False?' in Van den Berg AJ (ed), Legitimacy: Myths, Realities, Challenges (ICCA Congress Series Volume 18, Kluwer Law International 2015).

Menon S, 'The Special Role and Responsibility of Arbitral Institutions in Charting the Future of International Arbitration' (SIAC Congress 2018, Singapore, 17 May 2018) <www.supremecourt.gov.sg/Data/Editor/Documents/SIAC\%2oCongress\% 202018\%2 oKeynote\%2oAddress\%20\%2o(Checked\%2oagainst\%2odelivery\% 2owith\%2ofootnotes\%20-\%20170518).pdf> accessed 1 August 2018.

New York Arbitration Convention Website, 'Contracting States' (New York Arbitration Convention Website) < www.newyorkconvention.org/countries > accessed 28 June 2018.

New York Convention on the Recognition and Enforcement of Foreign Arbitral Awards (adopted 10 June 1958, entered into force 7 June 1959) 330 UNTS 38.

Note to Parties and Arbitral Tribunals on the Conduct of the Arbitration under the ICC Rules of Arbitration (30 October 2017).

Queen Mary University of London, 'International Arbitration: Corporate Attitudes and Practices 2008' (PricewaterhouseCoopers LLP 2008) <www.pwc.co.uk/en_UK/uk/ assets/pdf/pwc-international-arbitration-2008.pdf> accessed 28 June 2018.

Queen Mary University of London and White \& Case LLP, '2015 International Arbitration Survey: Improvements and Innovations in International Arbitration' (Queen Mary University of London and White \& Case LLP 2015) < www.arbitration .qmul.ac.uk/media/arbitration/docs/2015_International_Arbitr ation_Survey.pdf> accessed 1 August 2018.

Queen Mary University of London and White \& Case LLP, '2018 International Arbitration Survey: The Evolution of International Arbitration' (White \& Case LLP 2018 ) <www.arbitration.qmul.ac.uk/media/arbitration/docs/2018-International -Arbitration-Survey---The-Evolution-of-International-Arbitration-(2).pdf $>$ accessed 1 August 2018.

Rau, A S and Sherman E F, 'Tradition and Innovation in International Arbitration Procedure' (1995) 30 Texas International Law Journal 89.

Rules for Expedited Arbitrations of the Arbitration Institute of the Stockholm Chamber of Commerce (1 January 2017).

Santens AA and Kudrna J, 'The State of Play of Enforcement of Emergency Arbitrator Decisions' (2017) 34 Journal of International Arbitration 1. 
Schaefer JK, 'Borrowing and Cross-Fertilising Arbitration Laws - A Comparative Overview of the Development of Hong Kong and Singapore Legislation for International Commercial Arbitration' (1999) 16 Journal of International Arbitration 41.

Schellenberg Wittmer Ltd, 'The Singapore International Mediation Centre and the new AMA Procedure - finally what users have always wanted?' (Singapore International Mediation Centre 8 January 2015) <http://simc.com.sg/singapore-internationalmediation-centre-new-ama-procedure-\%EF\%AC\%81nally-users-always-wanted/> accessed 19 July 2018.

Secomb M and Tahsin A, 'SIAC unveils new, innovative rules' (White \& Case LLP 11 July 2016) < www.whitecase.com/publications/alert/siac-unveils-new-innovativerules $>$ accessed 10 July 2018.

Sheridan I, 'Qualitative Analytical Models for Arbitration' (2016) 33 Journal of International Arbitration 171.

SIAC, Arbitration Rules of the SIAC 4th Edition (1 July 2010) <www.siac.org.sg/images /stories/articles/rules/SIAC_Rules_2010_schedule_of_fees-revised_16Jan2013.pdf> accessed 27 December 2018.

SIAC 'SIAC 2010 CEO's Annual Report' (Singapore International Arbitration Centre 2010), <www.siac.org.sg/images/stories/articles/annual_report/SIAC_Annual_Re port_2010.pdf $>$ accessed 1 August 2018.

SIAC, 'SIAC 2011 CEO's Annual Report' (Singapore International Arbitration Centre 2011) < www.siac.org.sg/images/stories/articles/annual_report/SIAC_Annual_Re port_2011.pdf $>$ accessed 1 August 2018.

SIAC, Arbitration Rules of the SIAC 5 th Edition (1 April 2013) < www.siac.org.sg/images/ stories/articles/rules/SIAC\%202013\%2oRules_5th\%2oEdition.pdf> accessed 27 December 2018.

SIAC, Code of Ethics for an Arbitrator (2015) <www.siac.org.sg/images/stories/ articles/rules/Code_of_Ethics_Oct2015.pdf $>$ accessed 25 December 2018.

SIAC, 'Highlights of the SIAC Rules 2016' (30 June 2016) <www.siac.org.sg/images/ stories/articles/rules/SIAC\%2oRules\%202016_Cheat\%2oSheet_30June2016.pdf> accessed 25 December 2018.

SIAC, Arbitration Rules of the SIAC 6th Edition (1 August 2016) <www.siac.org .sg/images/stories/articles/rules/2016/SIAC\%2oRules\%202016\%2oEnglish_28\% 20Feb\%202017.pdf $>$ accessed 27 December 2018.

SIAC, Investment Arbitration Rules of the SIAC 1st Edition (1 January 2017) <http://siac .org.sg/images/stories/articles/rules/IA/SIAC\%2oInvestment\%2oArbitration\% 2oRules \%20-\%2oFinal.pdf $>$ accessed 27 December 2018.

SIAC, 'SIAC Annual Report 2017' (Singapore International Arbitration Centre 2017) <www.siac.org.sg/images/stories/articles/annual_report/SIAC_Annual_Report _2017.pdf> accessed 11 May 2018. 
SIAC, 'Application Form for Admission to SIAC Panel / SIAC IP Panel / SIAC Reserve Panel' <www.siac.org.sg/images/stories/documents/application_form/SIACPanelApplicationForm_Mar2017.pdf $>$ accessed 27 December 2018.

Siblesz H, 'The Role of Institutions in the Arbitral Process: The Permanent Court of Arbitration' (VII Congreso Latinoamericano de Arbitraje, Lima, 25 April 2013) <https://pca-cpa.org/wp-content/uploads/sites/175/2013/04/20130425-SG-Lima -LatAm-Congress8c61-1.pdf $>$ accessed 1 August 2018.

Villani A and Caccialanza M, 'Interim Relief through Emergency Arbitration: An Upcoming Goal or Still an Illusion?' (Kluwer Arbitration Blog, 14 July 2017) <http:// arbitrationblog.kluwerarbitration.com/2017/07/14/interim-relief-emergency -arbitration-upcoming-goal-still-illusion/> accessed 10 July 2018.

Vivekananda N, 'The SIAC Emergency Arbitrator Experience' (Singapore International Arbitration Centre 2013) < www.siac.org.sg/2013-09-18-01-57-20/2013-09-22-00-27-02/ articles/338-the-siac-emergency-arbitrator-experience > accessed 22 June 2018.

Werner J, 'Editorial' (1985) 2 Journal of International Arbitration 5. 